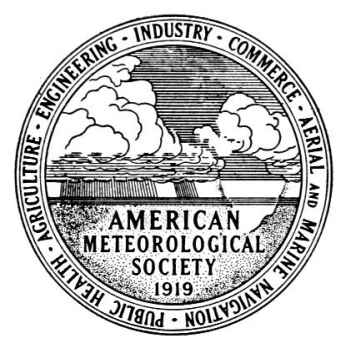

American Meteopological Society

announces

The Father James B. Macelwane Annual Awards

for original papers on meteorology,

The Howard T. Orville Scholarship in Meteorology,

and

The Howard H. Hanks, Jr., Scholarship in Meteorology

\section{Undergraduate awards}

\section{Undergraduate scholarships}

The Father James B. Macelwane Annual Awards were established by the American Meteorological Society to honor the late Rev. James B. Macelwane, S.J., geophysicist and Dean of the Institute of Technology, Saint Louis University, until his death in 1956. Father Macelwane was a world renowned authority on seismology.

The purpose of these awards is to stimulate interest in meteorology among college students. All registered undergraduate students of a college or university in the Americas are eligible to participate. The only restriction is that no more than two students may enter contest papers from any one institution.

The Society encourages original student papers concerned with some phase of the atmospheric sciences. Award stipends are supported by Weather Corporation of America, private meteorological consultants, Saint Louis, Mo. A stipend of $\$ 150.00$ is awarded to the author of the paper deemed most worthy by the judging committee. Additionally, stipends of $\$ 100.00$ and $\$ 50.00$ are awarded to second and third place winners.

The Howard T. Orville Scholarship in Meteorology honors the late Howard T. Orville, Head of the Naval Aerological Service, 1940-50, when he retired as Captain, USN. He later served in key industrial posts and as Chairman of the Advisory Committee on Weather Control in 1953. A graduate of the U.S. Naval Academy, his service was marked by many commendations. Capt. Orville was President of the American Meteorological Society, 1948-49. Through a bequest from the estate of Howard T. Orville, and contributions from members of his family, the Society gives an annual scholarship of $\$ 500.00$

The Howard H. Hanks, Jr., Scholarship in Meteorology honors the late Howard $\mathbf{H}$. Hanks, Jr. Mr. Hanks engaged for several years in applied and industrial meteorology until his very promising career was cut short by a plane crash. He was Vice President of Weather Corporation of America at the time of his death. A donation by William J. Hartnett, President of Weather Corporation of America, provides funds for the scholarship in the amount of $\$ 300.00$ per annum.

The Council of the Society has decided that the Orville Scholarship be given to a senior undergraduate meteorology major, and the Hanks Scholarship to a second student either in the senior or junior year.

The awarding of undergraduate scholarships in meteorology shall be based on academic excellence and achievement.

The candidate must be an undergraduate major in a meteorology department or other department actively engaged in work on some aspect of atmospheric science.

The candidate must intend to make atmospheric science his career and have completed at least 54 semester hours or their equivalent toward a Bachelor's degree.

The candidate applies by letter accompanied by a list of courses and grades in his major subject, and a listing of courses and grades in mathematics, physics, and other sciences. The candidate must be nominated by his major department and the nomination must be supported by a letter of recommendation from the department chairman or other designated department member reflecting the overall view of the department faculty. The Macelwane Awards and the Orville and Hanks Scholarships are administered by the Society's Committee of Judges for Undergraduate Awards.

Papers for the Macelwane Awards and applications for the Orville and Hanks Scholarships must be received not later than July 15, in the headquarters of the American Meteorological Society, 45 Beacon Street, Boston, Mass. 02108. Announcement of awards and the scholarship recipients will be made each year at the Annual Meeting of the Society. 
(Continued from announcements, page 557)

An energy partition evaporation recorder (Division of Atmospheric Physics Technical Paper No. 24, A. C. Dilley, 1974, 25 pp., n.p. paperbound, from the Commonwealth Scientific and Industrial Research Organization, P.O. Box 77, Mordialloc, Victoria 3195 Australia) describes an instrument which provides a near continuous measurement of evaporation from natural surfaces. Details are given of the instrument's construction, calibration, field operation, and performance.

Environmental geomorphology and landscape conservation, Volume II: urban regions (Benchmark Papers in Geology, Donald R. Coates, 1974, 454 pp., $\$ 25.00$, a Dowden, Hutchinson \& Ross Publication, distributed by Halsted Press, a division of John Wiley \& Sons, Inc., 605 Third Ave., New York, N.Y. 10016) discusses urban problems with respect to land and water.

The general circulation of the tropical atmosphere and interactions with extratropical latitudes, Volume 2 (Reginald E. Newell, John W. Kidson, Dayton G. Vincent, and George J. Boer, 1975, 371 pp., il., $\$ 65.00$ hardbound, from the MIT Press, 28 Carleton St., Cambridge, Mass. 02142) contains chapters on radiative heating in the atmosphere; heat budget; atmospheric energy cycle; cloudiness, precipitation, and vertical motion; semi-annual, annual, bi-annual, and longterm variations; large-scale wave disturbances in the tropical stratosphere; and further applications and outstanding problems.

Handbook of spectroscopy, volume II (J. W. Robinson, editor, 1974, 600 pp., $\$ 39.95$ hardbound, from CRC Press, Inc., 18901 Cranwood Parkway, Cleveland, Ohio 44128) contains sections on infrared, Raman, and ultraviolet absorption spectroscopy; electron spin resonance; mass spectral tabulations; and nuclear magnetic resonance.

Mesoscale modeling, forecasting and remote sensing research (AFCRL-TR-74-0253, Carl W. Kreitzberg, Donald J. Perkey, and John E. Pinkerton, 1974, 318 pp., Drexel University, from NTIS, above).

Pattern recognition principles (Applied Mathematics and Computation Series, No. 7, Julius T. Tou and R. C. Gonzalez; Robert Kalaba, series editor; 1974, 377 pp., $\$ 19.50$ clothbound, from Advanced Book Program, Addison-Wesley/ W. A. Benjamin, Inc., Reading, Mass. 01867) is a textbook written to provide engineers, scientists, and students involved in data analysis and information processes with an account of basic principles and available techniques for the analysis and design of pattern processing and recognition systems. Some of the principles could have applications for weather maps, radar displays, and satellite imagery, although these uses are not explicitly treated in the text.

Perspectives of biophysical ecology (Ecological Studies 12, David M. Gates and Rudolph B. Schmerl, 1975, 609 pp., $\$ 34.80$ hardbound, from Springer-Verlag New York, Inc., 175 Fifth Ave., New York, N.Y. 10010) describes the basic analytical models for primary productivity by plants and of thermal regulation in animals. Significant findings in physiologic ecology concerning plants and animals are reviewed and methods of bioclimatology are discussed.
Summary report of hydrodynamical-numerical (HN) model workshop and AGU topical meeting: hydrodynamicalnumerical models for coastal and open ocean areas (ENVPREDRSCHAFAC Tech. Paper No. 3-75, February 1975, 93 pp., n.p., paperbound, from NTIS, above) summarizes the proceeding of the HN model workshop and AGU topical meeting held at Monterey, Calif., in December 1974. A brief review is given of the history of HN models, the present state-of-the-art, and future needs.

The urban ecosystem: a holistic approach (Community Development Series, F. Stearns and T. Montag, editors, due April 1975, approx. 350 pp., $\$ 18.00$, a Dowden, Hutchinson, and Ross Publication distributed by Halsted Press, see above) approaches the urban system in a multi-disciplinary fashion, defining the "ecosystem" principles which underlie the functioning of urban centers. It is the report of the Institute of Ecology's Urban Ecosystem Workshop, attended by approximately 90 specialists from various natural and social sciences.

U.S. contribution to the Polar Experiment, part II POLEXGARP (south) (Joint U.S. POLEX Pancl, National Research Council, 1974, 33 pp., n.p., paperbound, from the Committee on Pelar Research, National Academy of Sciences, 2101 Constitution Ave., Washington, D.C. 20418) contains a summary of recommendations, introduction and background, and description of elements of a scientific program for POLEXGARP (South).

Yearbook of the Association of Pacific Coast Geographers, volume 36 (1974, 184 pp., \$5.00 paperbound, from Oregon State University Press, P.O. Box 689, Corvallis, Ore. 97330) includes articles on "Seasonal and Spatial Patterns of Air Pollution in Los Angeles County" and "Early Steps in the Classification of Climates." The Yearbook also contains abstracts of the papers presented at the Association's Annual Meeting held in San Diego, June 1973.

The following World Meteorological Organization publications are now available:

Surface irrigation (FAO Agricultural Development Papers, 1974, 160 pp., il., \$5.00, from Unipub, Box 433, Murray Hill Station, New York, N.Y. 10016) is a survey of the existing surface systems of irrigation. The book examines and compares various parameters of soil, water supply, topography, and cropping possibilities of these systems-as well as their technical requirements, practical applications, and costs.

The teaching of hydrology (UNESCO, 1974, 32 pp., \$3.30, from Unipub, above) presents basic methodological concepts in the teaching of hydrology, and material on specific aspects of hydrological education such as the need for practical training.

Three centuries of scientific hydrology, 1674-1974 (UNESCO/ WMO/IAHS, 1974, 123 pp., \$8.25, from Unipub, above) was prepared in honor of the Tercentenary of Scientific Hydrology in 1974. The book covers the historical evolution of the hydrological cycle concept; hydrometry-historical development and prospects in the light of modern technology; data collection systems and their impact; trends in hydrological analysis; and hydrology and water resources development. 